\title{
The American Labour MOVEMENT AND THE RESURGENCE IN UNION ORGANIZING
}

\author{
Kate Bronfenbrenner
}

In the last two decades, unions around the globe have watched in dismay as employers and governments have hastened to replicate US economic policies, labour laws, and union avoidance strategies. The result has been a race to the bottom for every aspect of the employment relationship - whether safety and health, contract enforcement, job security, pension benefits, or the right to organize.

In all of these areas, US employers have led the descent. Union density in the USA has dropped to 14 per cent for the first time in more than 60 years. For the last two decades, unions have been able to gain representation for fewer than 100,000 workers each year, far fewer than the 400,000 union jobs that are lost each year from plant closings, lay-offs, corporate restructuring, decertifications, and contracting out. Instead of the union-friendly labour law reform that unions hoped to achieve under a Democratic administration, they now watch as conservatives at all levels of government pursue an aggressive campaign to undercut severely all protective labour legislation. Deregulation, privatization, and liberalized trade policies threaten the security of workers throughout the economy.

Yet, at the dawn of a new century, the American labour movement shows signs of resurgence that make it as much a model for renewal as a prototype for decline. This resurgence is evident on the political front, where, through grassroots education and mobilization of their members and community allies, American unions have recently won victories in Congress on issues such as the minimum wage and maintaining restrictions on company unions. It is also evident in a series of recent bargaining victories at Verizon, Boeing, Kaiser Aluminum, United Parcel Service, and Continental Tire, where, through the use of creative and aggressive strategic campaigns, unions have successfully challenged some of the world's most powerful corporations.

We also see evidence of labour's revival in the new wave of student activism 
that has swept across American college campuses with a focus on antisweatshop campaigns and support for unionized campus service-workers. And we have witnessed a sea change in media attention to labour issues, with union victories and concerns making front-page news for the first time in decades.

But it is in organizing that the US labour movement's efforts at renewal have been most dramatic. Despite a rapidly deteriorating economic, political, and legal climate, for the last several years the AFL-CIO (the US national trade union federation), along with national and local unions, have together been engaged in an aggressive effort to improve significantly their organizing capacity and success. This has included shifting staff and financial resources into organizing, mobilizing leaders and members to support organizing campaigns, and developing and implementing more effective organizing strategies and tactics.

Recent victories such as the 74,000 homecare workers organized by the Service Employees International Union (SEIU) in Los Angeles, California; the nearly 10,000 workers organized by the Hotel and Restaurant Employees (HERE) at the MGM and Bellagio hotels in Las Vegas; the more than 26,000 airline reservation agents organized by the Communication Workers of America (CWA) at USAIRWAYS and the Machinists at United Airlines; or the recent Union of Needletrades, Industrial and Textile Employees (UNITE) victory for 5000 textile workers at Fieldcrest Cannon in North Carolina prove that some unions are winning, and winning big, even when faced with extremely aggressive employer opposition. More than that, we have seen a national commitment at the highest levels of the AFL-CIO and many of its largest affiliates to commit more resources to organizing and to 'organize at an unprecedented pace and scale' (Sweeney, Trumka, and ChavezThompson, 1995).

Slowly but surely these changes and initiatives are beginning to bear fruit. In 1998, for the first time in decades, American unions organized as many new workers as were lost from lay-offs, plant closings, decertifications, and contracting out. Unions won 1653 private sector representation elections involving 105,624 eligible voters. This is a 31 per cent increase from the 80,421 workers involved in National Labour Relations Board (NLRB) elections won by unions in 1996 and a 58 per cent increase in the number involved in winning elections in 1995. After a twenty-year decline, private sector first contract rates also increased to 68 per cent in 1998 from a low of 60 per cent in 1995 (BNA Plus, 1999). Unions also continue actively to organize state and local government workers in the American public sector while tens of thousands of US private sector workers are now seeking to 
organize outside of the traditional government supervised and regulated election process through community-based and industry-based direct pressure campaigns calling on employers to recognize the union and bargain a first agreement without going through a lengthy election process.

Many of these organizing gains were with new workers in new industries. More than half of the new workers organized are in health care, social services, hotel, entertainment, and other service sector units where women and people of colour predominate. Non-traditional community-based campaigns have been particularly effective among leased and contract employees such as janitors and home-health aides, construction workers, and low-wage workers in the hospitality industry. Not only are the majority of these workers women and people of colour, but many are new immigrants from Asia, Latin America, and the Carribean (BNA Plus, 1999).

By 1999, the combination of organizing victories and employment expansion in unionized industries resulted in a net gain of 265,000 in union membership, the first such gain in more than twenty years (AFL-CIO, 2000). The great American decline in union organizing may have finally bottomed out. Yet, in order to reverse the decline in organizing and regain their power at the bargaining table and in the broader community, American unions are going to have to organize millions, not hundreds of thousands, of workers each year. We can only hope that other nations learn both from our mistakes and our belated attempts at revitalization, so that they can stem their own decline before it reaches the same depths as in the USA.

\section{The legal framework for organizing in the USA}

The legal right to organize and to collective bargaining was first extended to the majority of private sector workers in the USA with the passage of the National Labour Relations Act (NLRA) in 1935. Today the NLRA covers the right to organize and collectively bargain for all private sector workers with the exception of railway and airline employees, who are covered under the Railway Labor Act; and domestic workers, agricultural workers, independent contractors, supervisors and managerial employees, who are excluded from all private sector collective bargaining legislation. Workers in federal, state, and local government did not gain legal protection for the right to organize until the 1960s and 1970s, and only then on a state-by-state basis. Today there are 43 different public sector labour relations laws and agencies in 37 states outlining the right to organize for government workers in those states. In 
thirteen states, mostly in the south and south-west, there are no collective bargaining laws covering public sector workers.

Private sector labour laws in the USA are administered by the NLRB and enforced by federal courts, whereas state labour laws are administered by state labour relations agencies and enforced by state courts. Most state labour laws mimic federal labour law in the procedures and regulations relating to organizing. These laws grant workers the right to organize and to bargain collectively through representatives of their own choosing and outline union and employer 'unfair labour practices', which are actions by either the union or the company that interfere with, threaten, penalize, or coerce workers in the exercise of these rights. When workers or unions believe the employer has committed unfair labour practices they file charges with the NLRB. However, because penalties for most employer violations are fairly minimal and include neither criminal penalties nor punitive damages, the law provides little disincentive for those employers determined to remain non-union.

The primary route to union representation in the USA is through the NLRB certification election process. Under this procedure a minimum of 30 per cent of workers in a specified bargaining unit (a group of workers which the NLRB believes have sufficient community of interest to bargain collectively for a single contract with the employer) petition the NLRB, either through individual signed authorization cards or multiple signatures on petition, to hold a secret ballot election to determine whether a majority of employees seek to be represented by the union.

Because of high turnover and inevitable loss of support for the union in response to aggressive employer anti-union campaigns, most unions wait until they have at least 70 per cent of the workers signed up prior to petitioning the NLRB. If the union can prove that the majority of the bargaining unit has signed a petition (or cards) authorizing the union to represent them in collective bargaining, then, prior to petitioning the NLRB, the union can go directly to the employer to demand that the employer voluntarily recognize the union as the exclusive representative for the workers in that bargaining unit and commence bargaining a first agreement, without first going through an election. Although in the public sector voluntary recognitions are quite common, in the private sector they are extremely rare and only happen in the context of extraordinary efforts by the union to leverage the employer to agree to recognize the union without first going through the certification election process.

In most cases, the employer refuses to recognize the union voluntarily and the union petitions the NLRB for a certification election. The NLRB then schedules a secret ballot election, on average, 30 to 50 days after the petition 
is filed. However, the election can be delayed by weeks, or even years, in those cases where the employer contests the appropriateness of the bargaining unit petitioned for by the union.

If the union wins a majority of the votes in the election ( 50 per cent plus one), or if the employer voluntarily recognizes the union, the NLRB certifies the union as the exclusive representative for the purposes of collective bargaining for that unit. That means that for at least one year after the unit is certified, or for as long as any collective bargaining agreement is in effect, no other union may bargain with the employer on behalf of workers in this unit. Once the union is certified the employer is required under the law to bargain in good faith in an attempt to reach an agreement. There is no requirement to reach an agreement and the only penalty for employers who refuse to bargain in good faith is a court order ordering them to go back to the bargaining table to attempt to reach an agreement.

\section{The roots of the decline in US organizing}

Many in the US labour movement mistakenly believe that their organizing problems began with President Reagan's anti-union initiatives in the 1980s. However, unlike other industrial countries, where free market economic policies and the recent dismantling of protective labour legislation have, in just a few short years, devastated union organizing efforts, the decline in US union density and organizing success began decades before the Reagan era. As long as US companies and their employees were reaping the benefits of an expanding world economy in the 1950s and 1960s, union leaders were able to keep their heads in the sand, ignoring the devastating long-term implications of a deteriorating legal, economic, and political climate. The full force of these environmental changes was not felt until the $1980 \mathrm{~s}$, too late easily to institute the serious strategic and structural changes necessary to reverse the decline.

In the 1930s and early 1940s US unions greatly increased their membership and power through aggressive organizing in the context of an expanding economy and a favourable political and social climate. In the decades that followed, actual union membership remained fairly stable, but overall density declined because unions failed to keep up with a rapidly expanding workforce. Some of this decline can be attributed to a series of structural changes in the US economy and workforce, including increased capital mobility, technological change, and changes in work organization, which have resulted in both significant job losses in unionized industries and dramatic growth in 
the largely unorganized service sector. These pressures on unionized industries were further exacerbated by government economic initiatives such as deregulation and free-trade policies (Bronfenbrenner et al., 1998).

The changing labour law climate has also contributed to the decline. Union density peaked in the late 1940 s, just before the enactment of the Taft-Hartley amendments to the National Labour Relations Act, which codified into law the pro-business decisions of a much more conservative, post-New Deal judiciary. Taft-Hartley expanded employer rights to oppose unions at the same time as it removed one of labour's most effective organizing tools: the secondary boycott. Reflecting the Cold War hysteria of the time, Taft-Hartley also included a clause requiring unions to sign 'noncommunist' affidavits if they wanted to be covered under the Act. In the years that followed an entire generation of the industrial labour movement's best organizers were purged from their unions for being communists, socialists, or 'fellow travellers'. With them went a wealth of strategic knowledge and organizing experience that is only now being regained, more than two generations later (Green, 1980: 195-205).

Although the decline in union density started in the years after TaftHartley, the true effect of these labour law changes was masked by the expanding economy. During the 1950s and 1960s unions focused their efforts on servicing their existing members rather than organizing industries and sectors that had been untouched by the wave of industrial organizing in the 1930s. It was not until the US post-war economic boom first faltered in the 1970 s, and unions first began to lose significant numbers through lay-offs, plant closings, and capital flight, that they felt the full force of their weakened labour rights. For now when they tried to organize they found employers committed to containing unionization to already-organized industries and aggressively opposing all union efforts to organize the unorganized.

Unions were ill prepared for the employers' onslaught. Earlier in the century in the textile mills in Lawrence, Massachusetts, or in the auto-plants in Flint, Michigan, organizers understood that their success depended on running slow, underground, community-based campaigns. Faced with employers who readily spied on, beat up, fired, blacklisted, and evicted workers for the slightest evidence of union sympathy, these organizers went house to house, neighbourhood to neighbourhood, building leaders, capitalizing on community networks and allies, and steadily preparing for more aggressive action (Kraus, 1947: 1-87; Cameron 1993: 117-69). For most industrial unions in the $1950 \mathrm{~s}$ and 1960s, however, organizing involved no more than handing out authorization cards outside the plant gate, followed by a few large meetings and some mass mailings. For other unions, particularly the building trades 
and the Teamsters, most organizing was accomplished top down, through visits by union officers to non-union employers. These strategies worked as long as unions controlled the market share of the industry and employer opposition was minimal. But once employers became more aggressive in their opposition to unions in the 1970 s and 1980 s, both union organizing activity and union organizing success plummeted (Chaison and Rose, 1991: 26).

As unions grew weaker, employers became more emboldened and sophisticated in their union-avoidance strategies. An entire industry of management consultants sprang up, feeding off employers eager to spare no expense to keep their workplaces 'union-free'. By the mid-1980s employers used anti-union consultants in 71 per cent of private sector union organizing campaigns (Bronfenbrenner and Juravich, 1995). By 1995 the number had increased to 90 per cent (Bronfenbrenner, 1997b).

Illegal anti-union activity also increased. According to Richard Freeman:

From 1960 to 1980 the number of all employer unfair labour practice charges rose fourfold; the number of charges involving a firing for union activity rose threefold; and the number of workers awarded back pay or reinstated into their jobs rose fivefold. (Freeman, 1985: 53)

By 1980, the overwhelming majority of employers aggressively opposed union organizing efforts through a combination of delays, harassment, discharges, misinformation, interrogation, threats, promises, bribes, and surveillance (Bronfenbrenner, 1994). Emboldened by President Reagan's unequivocal support for their anti-union agenda, as demonstrated by his discharge and replacement of striking air-traffic controllers, many openly flaunted labour law, secure in the knowledge that the penalties for even the most egregious violations were little more than a slap on the wrist.

Today, more than one-third of US employers discharge workers for union activity during organizing campaigns, more than half threaten a full or partial shutdown of their company if the union succeeds in organizing the facility, and between 15 and 40 per cent make illegal changes in wages, benefits and working conditions, give bribes to those who oppose the union, or use electronic surveillance of union activists during the organizing campaign (Bronfenbrenner, 1997b). In short, US employers faced with organizing campaigns, stop at nothing to create a climate so fraught with fear, conflict, suspicion, and intimidation, that workers long for the time before the union drive began.

Employers in the USA engage in these aggressive actions with little fear of any significant legal penalties from the NLRB or the courts. Even in the most 
serious cases, such as the CWA's 1994 campaign at Sprint's Hispanic marketing division in San Francisco - where the NLRB and the courts found Sprint guilty of more than 50 egregious labour law violations during the organizing campaigns, including fabricating evidence, bribes, threats, surveillance, discharges, and ultimately shutting down and transferring work in direct response to the union campaign - the only penalty was an order to refrain from engaging in similar violations if they were ever to open again.

Not surprisingly, the intensity of these employer campaigns has had a devastating impact on union organizing success. Research has consistently found that most individual anti-union employer tactics are associated with union win rates 10 to 20 per cent lower than in units where they are not utilized. In addition, when included in a regression equation controlling for the influence of election background, bargaining-unit demographics, and union tactic variables, these individual employer actions decrease the probability that the union will win the election by between 3 per cent and 22 per cent, whereas each additional aggressive anti-union tactic the employer uses reduces the probability of the union winning the election by 7 per cent (Bronfenbrenner, 1994, 1997b; Bronfenbrenner and Juravich, 1998).

Given the evidence, it is not surprising that many researchers have concluded that employer opposition and weak and poorly enforced labour laws are the primary causes of the declining organizing success of US unions. Yet, unions in the USA cannot simply blame external factors for their failure to organize. They themselves must take a significant share of the blame. In the 1950 s and 1960s, when unions had the resources and power to launch massive organizing campaigns, taking on entire industries, they failed to do so. Equally damaging, they completely ignored, and in many cases consciously neglected, whole sectors of the economy because they were dominated by low-wage women and people of colour (Bronfenbrenner et al., 1998). In part this was due to prejudice but it was also due to the mistaken belief that these workers were less interested in unions and these industries were more difficult to organize. Many unions have held on to this belief in the $1990 \mathrm{~s}$, despite the fact that research has consistently shown that women workers, low-wage service workers, and people of colour are just as likely, if not more likely, to organize (Bronfenbrenner, 1993).

For decades US unions also neglected to organize professional, technical, and clerical workers in white-collar occupations, once again convinced that these workers were less interested in unions than their blue-collar counterparts. This changed somewhat in the 1960s and 1970s, when, with the advent of public sector collective bargaining, public sector teachers, office workers, and administrators began to flock to unions in droves. Although by the 
1990 s, only 16 per cent of the total US workforce was employed by state, local, and federal government entities, a third of the workers represented by AFLCIO affiliates were employed in the public sector and public sector union density stabilized above 35 per cent. These public sector workers were able to organize into unions and bargain first agreements largely free of the aggressive employer opposition that is so prevalent in the private sector, which explains why public sector white-collar workers have been so much more likely to organize than their private sector counterparts (Juravich and Bronfenbrenner, 1998).

In the 1970s, with the elimination of the healthcare worker exclusion from the National Labour Relations Act, there was a burst of organizing activity among private sector hospital and nursing home employees. Similarly in the 1980s, unions such as District 65 of the United Auto Workers (UAW) won several major campaigns among university clerical workers. Coupled with victories in the public sector, these efforts brought thousands of women and people of colour into the labour movement. Yet even these gains were not enough to stop the haemorrhaging of union membership in labours' former strongholds in auto, steel, construction, electronics, and textiles (Bronfenbrenner et al., 1988).

Even by the 1980s, when it was difficult for any union leader in the USA to ignore the hard numbers of labour's decline, few unions were willing or able to rise to the organizing challenge. Instead, most concentrated their resources on servicing and bargaining for a shrinking membership. The majority of those that did organize ran very weak top-down organizing campaigns, which were no match for most employers. Some unions were organizing and winning despite employer opposition, however, and despite the deteriorating organizing climate. The challenge for the US labour movement was to determine why these unions were more successful and which tactics and strategies contributed most to their success.

\section{Factors contributing to union organizing success}

Although there has been extensive research on factors contributing to the decline in union organizing in the USA, very few studies have examined the role played by union tactics in the organizing process. In part this is because many industrial relations researchers are not convinced that union tactics play a significant role in determining election outcomes. Some, like Dickens (1983), believe that union tactics are entirely reactive, determined solely by management tactics, and therefore should not and do not need to be 
included in organizing research models. Others may believe that union tactics matter, but are unable to include them in their research models, both because they have limited understanding of the tactics that unions have available to them in organizing drives, and because they lack access to union campaign data. Thus most industrial relations research on private sector organizing in the USA continues to focus primarily on the election, unit, and employer variables easily accessible in NLRB databases.

In 1988, in cooperation with the Organizing Department of the AFL-CIO, I launched the first of a series of studies specifically designed to expand the body of knowledge available to the labour movement and scholars of the labour movement regarding factors contributing to union success or failure in certification election campaigns. Through surveys of leading organizers in private and public sector organizing campaigns, we have been able to determine which union tactics have the most positive impact on union organizing success while controlling for the impact of election environment, organizer background, bargaining unit demographics, and employer characteristics and tactics (Bronfenbrenner, 1993, 1997a, 1997b, 1997c; Bronfenbrenner and Juravich 1998; Juravich and Bronfenbrenner, 1998).

The findings from these studies have been consistent and clear. Unions that win elections in the context of aggressive employer opposition, tend to run very different campaigns from those that lose. In fact, union strategies and tactics were found as a group to matter just as much, if not more, in determining election outcomes than other groups of variables including bargaining unit demographics, employer characteristics and tactics, and the broader organizing climate. This is one of the most striking findings of the research because this means that the one element of the election process that US unions control, namely their own organizing strategy and tactics, can make a significant difference in determining whether they win or lose elections, even in a hostile organizing climate.

What we found is that unions are most likely to win certification election campaigns when they run aggressive and creative campaigns utilizing a grassroots, rank-and-file intensive strategy, building a union and acting like a union from the very beginning of the campaign. Thus, campaigns where the union focused on person-to-person contact, house calls, and small-group meetings to develop leadership and union consciousness and inoculate workers against the employer's anti-union strategy were associated with significantly higher win rates than traditional campaigns, which primarily utilized gate leafleting, mass meetings, and glossy mailings to contact unorganized workers.

This is not to say that there is something inherently wrong with leaflets and mailings during organizing campaigns. Rather, what our research shows is 
that these leaflets and mailings act as a proxy for traditional campaigns where the union's energy is focused on indirect means of communication rather than on the personal contact and leadership development necessary to build the union and counteract the employer campaign. Unlike leaflets and mailings, person-to-person contact through house calls and small group meetings is an essential and effective means for organizers to listen to workers' concerns, allay their fears, and mobilize them around the justice and dignity issues that matter enough to them to challenge the employer and win, regardless of the brutality and intensity of the employer campaign.

Unions were also more successful when they encouraged rank-and-file participation in and responsibility for the organizing campaign. More than any other single variable, having a large, active, rank-and-file committee representative of all the different interest groups in the bargaining unit was found to be critical to union organizing success, increasing the probability of the union winning the election by as much as 20 per cent. With employers aggressively campaigning against the union eight hours a day in the workplace, these committees are the most effective vehicles for generating the worker participation and commitment necessary to counteract the fears and misinformation created by the employer campaign. Representative rank-and-file committees are also essential in order for the union to keep in touch with the issues and concerns of the workers they are attempting to organize. But perhaps most important of all, these committees give workers a sense of ownership of the union and the organizing campaign and a sense that they are part of a democratic and inclusive organization. Rank-and-file leadership and ownership of the union campaign also make it much more difficult for the employer to paint the union as an outside third party.

Escalating pressure tactics in the workplace and the community such as petitions, mass grievances, T-shirt or button days, rallies, public forums, or leveraging the employer through suppliers, investors, stockholders or customers, were also found to have a significant positive impact on union organizing success. These actions are important because they build worker solidarity, develop leadership, reinforce commitment among pro-union workers and help to convince undecided voters that they can safely support the union. These tactics also actively demonstrate support for the union among the workers and the broader community and can therefore compel the employer to scale back its anti-union campaign.

According to our findings, union success also depends on developing a long-range campaign strategy that incorporates building for the first contract into the original organizing process. Union win rates were significantly 
higher in campaigns where the union started preparing for the first contract before the election by conducting bargaining surveys, selecting the bargaining committee, and involving the workers in researching and preparing proposals. These tactics are important because they build worker confidence that the union is going to win the election and successfully bargain a first agreement and because they demonstrate to the workers that they are going to play an active role in the collective bargaining process.

Unions are also more successful in organizing when there is an emphasis on developing a culture of organizing that permeates everything that the union does. This includes a serious commitment of staff and financial resources to organizing at both the local and international levels. Organizing costs money - for staff, training, cars, gas, hotels, literature, computers, and phones. In a time of declining members and dues, most unions are struggling with how best to allocate increasingly scarce resources. Thus, unions will only be successful in transferring sufficient resources into organizing if they are able to convince union leaders and their members that the future of their union depends on organizing, and organizing depends on transferring resources from servicing to organizing.

One of the most effective ways to mobilize membership support for organizing is through the recruitment, training, and utilization of member organizers from already-organized units. These volunteers are not only important because they can inexpensively supplement scarce organizing staff resources. Their most important contribution is in their ability to speak sincerely and powerfully from their own experiences of organizing and winning a first contract. Much more than paid professional organizers, these volunteers can credibly convince unorganized workers that not only is it possible to organize and win but it is also worth the risk, fear, and conflict that it takes to do so.

Lastly, union organizing success depends on strategic research and targeting that carefully assesses whether the workers are really ready to organize; whether the union has the expertise, experience, and resources to organize workers in this industry; and perhaps most important of all, whether the union has the leverage to gain a first contract for the workers once the election is won.

At a time when private sector union density has dropped down to 9 per cent and most union organizing campaigns barely get off the ground, unions can ill afford to waste precious time and resources on campaigns they are doomed to lose. They need to focus their energies on the workers and units where they are most likely to win, and on the units that, once won, will have the greatest impact on strengthening their bargaining power in their existing 
units. Unions that attempt to organize any type of worker in any industry, with no regard to the workers' experience or bargaining leverage in the enterprise, community, or industry, risk seriously diluting their power, and the power of other unions, at a time when they most need to concentrate their power in any way they can.

In the late 1980s, when the first of these organizing studies was conducted, we found many of the individual components of the comprehensive strategy described above to be associated with win rates 10 to 30 per cent higher than win rates in campaigns that did not use those tactics (Bronfenbrenner 1997a). The tactics associated with the highest win rates included having a representative committee; house calling the majority of the unit; using escalating pressure tactics such as solidarity days; establishing a rank-and-file bargaining committee before the election; using member volunteer organizers; and focusing on issues of dignity and justice rather than just bread-andbutter issues. We also found that when union building tactics were included in a regression equation controlling for the influence of other election campaign variables, most were associated with as much as a 3 per cent increase in the percentage of votes received by the union and as much as a 10 per cent increase in the probability of the union winning the elections. The probability of the union winning the election also increased by 10 per cent for each additional union building tactic used by the union during the organizing campaign (Bronfenbrenner and Juravich, 1998).

Unfortunately, the study also found that, in the late 1980s, only a very small number of unions were using a comprehensive union building strategy in their certification election campaigns. Fewer than a third of the unions surveyed had representative committees, house called the majority of the members of the unit, held ten or more small-group meetings, or focused on dignity and fairness as the primary issues. Even fewer started preparing for the first contract before the election or used escalating pressure tactics such as solidarity days, community coalitions, rallies, job actions or media campaigns.

Unions were able to win every election in the extremely small number of campaigns ( 3 per cent) where the union ran a comprehensive campaign using five or more of the union building tactics described above. However the win rate was only 41 per cent in campaigns where they used fewer than five union-building tactics.

Since that time, we have conducted two follow-up studies of NLRB election campaigns, one of elections that took place in 1994 and one of elections that took place between 1993 and 1995 (Bronfenbrenner, 1997b, 1997c; Bronfenbrenner and Juravich, 1998). Although overall the results from these 
studies are consistent with the findings from the 1980s study there are two important differences. First, although employer campaigns have dramatically increased in intensity and effectiveness, the nature and intensity of union campaigns have increased to a much smaller extent. It is true that more unions are committing more staff and financial resources to organizing, and more are also using representative committees, person-to-person contact, and escalating pressure tactics, and preparing for the first contract during the organizing campaign. However, although the percentage of employers that run aggressive campaigns increased from 21 per cent to 64 per cent, the percentage of unions that run aggressive campaigns increased from 3 per cent to only 30 per cent.

Second, in the 1990s individual union tactics variables were found to be associated with win rates only 2 per cent to 16 per cent higher than campaigns in which the tactics were not used. A few tactics, when measured individually, such as house calling the majority of the unit, were now associated with lower win rates than campaigns where they were not used. In the 30 per cent of the campaigns where the union did use five or more union building tactics the win rate was 50 per cent, compared to 36 per cent where they used fewer than five tactics and 27 per cent where no union building tactics were used. More important, for the 6 per cent of the campaigns where the union ran a true multifaceted comprehensive campaign, using ten or more union building tactics, the win rate increased to 72 per cent (Bronfenbrenner, $1997 \mathrm{c}$ ). When a variable measuring the number of union tactics used was included in a regression equation controlling for the influence of other election campaign variables, including employer tactics, the probability of the union winning the election increased by 9 per cent for each additional union building tactic used. At the same time the probability of the union winning the election declined by 7 per cent for each additional anti-union tactic the employer used (Bronfenbrenner and Juravich, 1998).

The results of the 1990s data show that, in the USA today, when employer campaigns are dramatically increasing in their intensity and the broader economic, social and political climate is becoming more and more hostile to organizing, the strategies and tactics that unions use matter now, more than ever. However, there are no silver bullets; there is no single tactic that guarantees union victory. Instead union success depends on utilizing a multifaceted comprehensive strategy incorporating as many rank-and-file intensive union building strategies as possible, including person-to-person contact, rank-and-file leadership development, escalating pressure tactics, and building for the first contract during the organizing campaign. The more comprehensive and multifaceted the union strategy is during an 
organizing campaign, the more union building strategies it uses, the more likely it is to win the election.

The data also show that in the last ten years more and more organizers are beginning to try to run more aggressive organizing campaigns. However, their approach to organizing has been piecemeal. They have been adding one or two new tactics to their traditional organizing practice without incorporating them into a more cohesive and comprehensive strategy. Thus more unions may be house calling the majority of the unit, but if they are using only professional staff to conduct the house calls, without building an effective rank-and-file committee and without using volunteer organizers from other units, those house calls are much less effective. More unions are also using representative committees, but because they are not always actively involving them in an aggressive and creative campaign, their positive impact is greatly muted. We also see more unions resorting to external pressure tactics targeted at investors, suppliers, or customers, both in voluntary recognition and first contract campaigns.

We found evidence in our research that in the past few years the shortage of skilled, experienced organizers, particularly women and people of colour, has reached crisis proportions. Today, just as ten years ago, just over half of the campaigns had the needed ratio of one full-time organizer per 100 eligible voters. Even more disturbing, where ten years ago 12 per cent of lead organizers were women and 15 per cent were people of colour, today the percentage of women lead organizers has only increased to 16 per cent and the percentage of lead organizers who are people of colour has actually dropped to 9 per cent. Even in campaigns with a majority of women, only 23 per cent have a woman lead organizer, while in campaigns with a majority of workers of colour, only 16 per cent have a person of colour as the lead organizer. This occurs despite the fact that win rates are significantly higher in units with a majority of women with a woman lead organizer (50 per cent versus 39 per cent for a male lead organizer) and in units with a majority of workers of colour for a lead organizer of colour (64 per cent versus 35 per cent).

Significant gains have been made in recruiting more women and people of colour to staff organizing campaigns. Today more than 40 per cent of all NLRB campaigns and 58 per cent of campaigns in primarily female units have at least one woman organizer staffing or leading the campaign, whereas a third of all campaigns and 58 per cent of campaigns with a majority of workers of colour have at least one person of colour on staff or leading the campaign. Most of these organizers are African-American or Hispanic, whereas fewer than 2 per cent are Asian, despite the large numbers of Asian workers currently participating in organizing campaigns. 


\section{Conclusion}

Our research on organizing campaigns clearly demonstrates that, in the 1990s, more unions in the USA were consistently adopting the more comprehensive approach that is required to win elections in the current organizing climate. Not surprisingly, it is these unions that have won the lion's share of the union victories in recent years. These are also the unions that are committing the most resources to organizing, recruiting the most women and people of colour to their organizing staff, running the most election campaigns, winning the largest units, and are contributing the most to the recent upturn in union organizing numbers. Unfortunately they still represent the minority, which is why the US labour movement remains so far from organizing the millions of new workers it needs to regain its bargaining and political power.

There is no question that free market economic policies, liberalized trade practices, and the elimination or weakening of protective labour legislation have greatly increased the costs and risks to workers and unions attempting to organize in every nation. But the findings from our organizing contract research also hold out the promise and possibility that unions can organize and win, even in the most hostile organizing climate, if they are willing to commit to a much more costly and comprehensive organizing strategy.

But they cannot delay. For too many decades unions in the USA failed to accept responsibility for their declining numbers and power. Not only did they continue to blame external forces for their organizing difficulties, but they also continued to seek to be rescued by their political allies, blinded by the belief that any organizing renewal was entirely dependent on first achieving significant labour law reform. In doing so they failed to understand that the deteriorating legal climate for organizing has always been a direct result of their declining numbers and political power. In fact, only through organizing massive numbers of new members in every sector of the economy, will US unions once again have the political leverage to ensure more progressive and more effective labour legislation.

This organizing will need to be achieved through massive numbers of NLRB elections in larger and larger units but increasingly it will also need to go beyond the traditional board certification election process to organize workers in industries and occupations that are either too large, too diffuse, or too contingent, to be successfully organized under the certification election model. For these employers, many of whom are the richest and most powerful multinational corporations in the world, what is required is a comprehensive campaign simultaneously organizing the rank-and-file workers in the 
workplace and the community from the bottom up, while leveraging the employer through its investors, suppliers, customers, owners, and subsidiaries from the top down.

As difficult as it is to achieve, a certification election victory is just the first step in the organizing process. For, without a first agreement, there are no new members, no contract gains, and the union often ends up being decertified or withdrawing in a few years. Despite progress on the organizing front, today the overall private sector first contract rate is only 60 per cent. This means that fewer than a quarter of the private sector workers who attempt to organize under the NLRB are able to gain representation under a union contract.

This high failure rate occurs both because the majority of employers continue their anti-union campaign after the election is won and because the majority of unions fail to continue an aggressive, rank-and-file intensive strategy after the election campaign. What our research has found is that unions' success in winning first agreements and staying organized after the first contract is reached depends on continuing and intensifying the same kind of multifaceted, rank-and-file intensive campaign that is so essential to the initial organizing campaign. The organizing never stops.

But unions engaging in such organizing cannot and should not assume that they are simply mobilizing new workers to become dues payers for the status quo. Workers who organize today are not going to be willing to take on the risks or put in the hard work of organizing if they are not going to be given a voice and a seat at the table once the union has won. These new workers will come into the labour movement with new issues and new demands and with the expectation that the union will continue to be the same activist and democratic organization it was during the organizing campaign through the first contract and beyond.

Nor can we assume that there is some other, less difficult and less adversarial, model that would more gently convince employers to grant union recognition and utilize new, more collaborative, industrial relations strategies for the new millennium. The evidence from the last decade is very clear. Employers in the USA today, whether foreign-based multinationals or US-based family businesses, manufacturing or healthcare, high tech or low wage, will not and do not voluntarily recognize unions in the absence of the expression of union power in the workplace and broader community.

For many years labour's declining political power in the USA was cushioned by the post-World War II economic boom. By the time most of the US labour movement woke up and recognized that they were in a crisis, they faced a hostile President and a global market economy. For other industrial 
nations the crisis has developed much later and much more quickly. But today, whether in Great Britain, Brazil, Korea, or New Zealand, it is no less acute.

Unions in the USA are learning that, even in the most hostile organizing climate, workers do organize and unions can win, if they are willing to commit to a more aggressive and comprehensive organizing strategy which slowly but steadily builds the union from the bottom up. This is how unions everywhere have always had to organize in the absence of strong enforceable protective labour legislation and this is how more and more unions around the world will have to organize in an era of free markets, free trade, deregulation, and multinational corporate restructuring. It is a great challenge, but it is also a great opportunity, to build a stronger, and more united labour movement around the globe.

\section{References}

AFL-CIO (2000) 'Union Membership Shows Biggest Growth in Over 20 Years, According to New Government Data', AFL-CIO Press Release, 19 January 2000.

BNA Plus (1999) NLRB Representation and Decertification Elections Statistics, Washington DC: Bureau of National Affairs.

Bronfenbrenner, K. (1993) Seeds of Resurgence: Successful Union Strategies for Winning Certification Elections and First Contracts in the 1980 s and Beyond, PhD Dissertation, Cornell University.

Bronfenbrenner, K. (1994) 'Employer Behavior in Certification Elections and FirstContract Campaigns: Implications for Labor Law Reform', in S. Friedman, R. Hurd, R. Seeber, and R. Oswald (eds) Restoring the Promise of American Labor Law, Ithaca NY: ILR Press, pp. 75-89.

Bronfenbrenner, K. (1997a) 'The Role of Union Strategies in NLRB Certification Elections', Industrial and Labor Relations Review, 50 (2): 195-221.

Bronfenbrenner, K. (1997b) 'The Effects of Plant Closing or Threat of Plant Closing on the Right of Workers to Organize', supplement to Plant Closings and Workers Rights: A Report to the Council of Ministers by the Secretariat of the Commission for Labor Cooperation, Dallas TX: Bernan Press.

Bronfenbrenner, K. (1997c) 'Organizing in the NAFTA Environment', New Labor Forum, 1 (1): 50-60.

Bronfenbrenner, K. and Friedman, S., Hurd R., Seeber R. and Oswald, R. (eds) (1998) Organizing to Win: New Research on Union Strategies, Ithaca NY: ILR Press.

Bronfenbrenner, K. and Juravich, T. (1995) The Impact of Employer Opposition on Union Certification Win Rates: A Private/Public Sector Comparison, Washington DC: Economic Policy Institute Working Paper No. 113. 


\section{KATE BRONHENBRENNER}

Bronfenbrenner, K. and Juravich, T. (1998) 'It Takes More Than House Calls: Organizing to Win with a Comprehensive Union-Building Strategy', in K. Bronfenbrenner, S. Friedman, R. Hurd, R. Seeber, and R. Oswald (eds) Organizing to Win: New Research on Union Strategies, Ithaca NY: ILR Press, pp. 19-36.

Cameron, A. (1993) Radicals of the Worst Sort, Urbana IL: University of Illinois Press.

Chaison, G. N. and Rose, J. B. (1991) 'The Macro Determinants of Union Growth and Decline', in G. Strauss, D. Gallagher, and J. Fiorito (eds) The State of the Unions. Madison WI: IRRA, pp. 3-46.

Dickens, W. T. (1983) 'The Effect of Company Campaigns on Certification Elections: Law and Reality Once Again', Industrial Relations, 36: 323-34.

Freeman, R. (1985) 'Why Are Unions Faring Poorly in NLRB Representation Elections?' in Kochan, T. A. (ed.) Challenges and Choices Facing American Labor, Cambridge MA: MIT Press, pp. 45-64.

Green, J. (1980) World of the Worker: Labor in Twentieth Century America, New York NY: Hill \& Wong.

Juravich, T. and Bronfenbrenner, K. (1998) 'Preparing for the Worst: Organizing and Staying Organized in the Public Sector', in Bronfenbrenner, K., Friedman, S., Hurd, R., Seeber, R. and Oswald, R. (eds) Organizing to Win: New Research on Union Strategies, Ithaca NY: ILR Press, pp. 262-82.

Kraus, H. (1947) The Many and the Few, Los Angeles CA: Plantin Press.

Sweeney, J., Trumka, R. and Chavez-Thompson, L. (1995) A New Voice for American Workers: Rebuilding the American Movement - A Summary of Proposals from the Unions Supporting John J. Sweeney, Richard Trumka, and Linda Chavez-Thompsom, Washington DC: New Voice for American Workers. 